\title{
ANALISIS KESELARASAN ANTARA PENGGUNAAN LAHAN SAAT INI DENGAN ALOKASI RUANG DAN STATUS LAHAN (STUDI KASUS KABUPATEN BOGOR BAGIAN BARAT)
}

\section{Conformity Analysis Between Existing Land Use with Allocation of Space and Land Status (Case Study in Bogor Regency of West Section)}

\author{
Laila Mardlotillah Yogaswara ${ }^{1)^{*}}$, Darmawan2), dan Asdar Iswati2) \\ 1) Alumni Program Studi Ilmu Perencanaan Wilayah, Sekolah Pascasarjana IPB, Jl. Raya Darmaga, Gedung Andi \\ Hakim Nasoetion Kampus IPB Darmaga Bogor 16680 \\ 2) Departemen Ilmu Tanah dan Sumberdaya Lahan, Fakultas Pertanian IPB, Jl. Meranti Kampus IPB Darmaga \\ Bogor 16680
}

\begin{abstract}
Proliferation of administrative region has been done and will to continue to happened, such as the discourse of the western division of the Bogor Regency. The formation of a new autonomous region requires significant preparation. Among others, the utilized of physical resource areas. Analysis of conformity between existing land use with spatial planning and land status is very relevant to the expansion plan of an area. The information obtained is the basis for a new spatial planning. Analysis of overlay existing land use, with spatial planning and land status in the western part of Bogor Regency has been done. The results suggest that there is inconsistency between conservation forest areas are land uses other than forest namely: mixed farming, settlements, plantations, mining, rice fields and moors with status of cultivation right and Proprietary. In the plantation area are leasehold status of the activity of farming communities. Mixed farms as resulted of the society activity was found in the whole society of the space allocation is variously.
\end{abstract}

Keywords: Conformity, land use, regional autonomy

\begin{abstract}
ABSTRAK
Pemekaran wilayah sudah banyak dilakukan dan tampaknya akan terus terjadi, seperti wacana pemekaran Kabupaten Bogor bagian Barat. Pembentukan wilayah otonomi baru memerlukan persiapan yang penting. Antara lain dalam level pemanfaatan sumberdaya fisik wilayah. Analisis keselarasan antara penggunaan lahan saat ini dengan alokasi ruang dan status lahan sangat relevan dengan rencana pemekaran suatu wilayah. Informasi yang diperoleh merupakan dasar dalam penataan ruang wilayah baru. Analisis tumpangtindih antara penggunaan lahan saat ini, alokasi ruang yang ada dan status lahan di wilayah Kabupaten Bogor bagian Barat telah dilakukan. Hasilnya menjelaskan bahwa terdapat ketidakserasian antara Kawasan Hutan Konservasi karena adanya penggunaan lahan lain selain hutan yaitu: kebun campuran, permukiman, perkebunan, pertambangan, sawah dan tegalan dengan status lahan Hak Guna Usaha dan Hak Milik. Dalam Kawasan Perkebunan status Hak Guna Usaha terdapat aktivitas masyarakat bercocok tanam. Kebun campuran hasil dari aktivitas masyarakat yang dijumpai pada seluruh alokasi ruang dan status lahan yang berbeda dengan luas yang beragam.
\end{abstract}

Kata kunci: Keselarasan, penggunaan lahan, otonomi daerah

\section{PENDAHULUAN}

Identifikasi untuk keselarasan antara penggunaan lahan, status lahan dan alokasi ruang akan bermanfaat memberikan arahan dalam pemekaran suatu wilayah. Kabupaten Bogor bagian Barat merupakan wilayah di Kabupaten Bogor yang belum berkembang karena akses jalan dan penggunaan lahan yang terbatas. Oleh karena itu, data mengenai penggunaan lahan pada saat ini akan sangat bermanfaat dalam pengembangan penggunaan lahan di masa datang yang dapat digunakan sebagai acuan dalam pemanfaatan lahan secara optimal. Selain itu, data penggunaan lahan tersebut dapat digunakan untuk menyusun tata ruang yang baik mengingat wilayah direncanakan menjadi wilayah otonom baru (Bappeda, 2006)

Penelitian ini dilakukan untuk melihat penggunaan lahan pada saat ini dikaitkan dengan alokasi ruang dan status lahan. Keselarasan ketiganya merupakan faktor penting untuk pengembangan wilayah. Terkait keselarasan tersebut, pada penelitian sebelumnya yang dilakukan oleh Marisan (2006) diketahui adanya ketidaksesuaian atau penyimpangan pemanfaatan ruang dengan rencana pola ruang RTRW Kabupaten Bogor Tahun 2005-2025. Penyimpangan alokasi ruang terbesar terjadi pada penggunaan lahan kebun campuran di Kawasan Hutan 
Lindung dan Hutan Produksi yang berada pada kelerangan agak curam hingga curam $(15->45 \%)$. Selanjutnya menurut Maharani (2011) diketahui bahwa masyarakat yang mengolah tanah di lahan Hak Guna Usaha dan Tanah Negara Dikuasai, masyarakat memiliki hak garap yang diberikan pihak PT. Perkebunan Nusantara (PTPN) VIII dan pihak Taman Nasional Gunung Halimun-Salak (TNGHS). Petani yang menggarap lahan tersebut rata-rata adalah petani gurem. Dengan bertambahnya kebutuhan masyarakat akan lahan dalam penelitian Lambin et al. (2003) maka perkembangan penggunaan lahan khususnya pertanian mengalami ekspansi ke dalam hutan, dan seluruh bagian dimuka bumi untuk memenuhi kebutuhan akan makanan. Ekspansi pertanian bergerak diantara penggunaan lahan lainnya yang diikuti oleh peraturan pemerintah, ekonomi dan meningkatnya populasi. Ekspansi pertanian terbesar pada abad ke 20 terjadi di Asia bagian selatan dan tenggara Asia.
Tujuan dari penelitian ini adalah: (1) Mengidentifikasi jenis-jenis penggunaan lahan saat ini di Kabupaten Bogor bagian Barat dan (2) Mengevaluasi keserasian antara penggunaan lahan, alokasi ruang dan status lahan di wilayah Kabupaten Bogor bagian Barat.

\section{BAHAN DAN METODE}

Lokasi penelitian berada pada Wilayah Kabupaten Bogor bagian Barat yang terdiri dari empat belas Kecamatan, yaitu: Kecamatan Nanggung, Leuwiliang, Leuwisadeng, Pamijahan, Cibungbulang, Ciampea, Tenjolaya, Tenjo, Rumpin, Jasinga, Parungpanjang, Sukajaya, Cigudeg, dan Dramaga. Pemilihan kecamatan dalam penelitian didasarkan pada laporan penelitian awal pengembangan wilayah Kabupaten Bogor (Bappeda, 2006). Luas wilayah penelitian ialah 11,241 ha. Secara geografis posisi wilayah ini berada pada $6^{\circ} 19^{\prime}-6^{\circ} 47^{\prime} \mathrm{LS}$ dan $106^{\circ} 1^{\prime}-$ $107^{\circ} 103^{\prime}$ BT (Gambar 1).

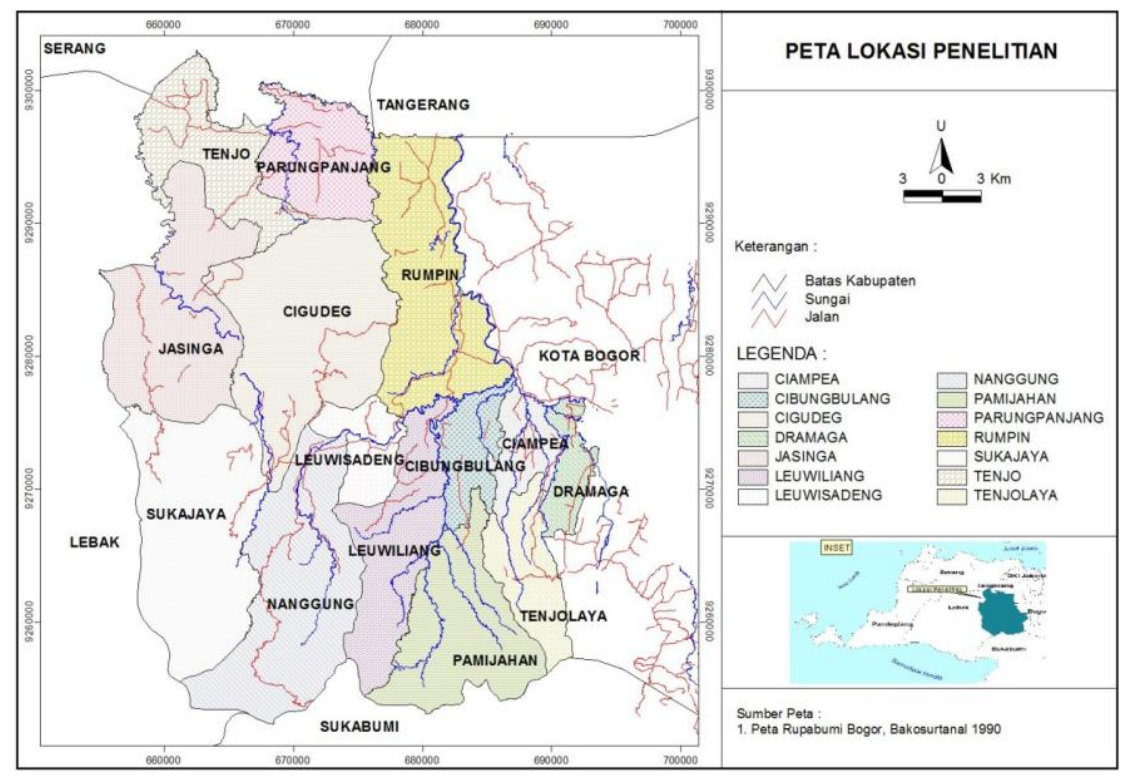

Gambar 1. Lokasi penelitian

\section{Bahan dan Alat}

Peralatan yang digunakan dalam penelitian ini meliputi peralatan teknis untuk survei lapang yaitu : GPS, alat tulis, kamera, dan perekam suara. Peralatan lainnya ialah perangkat komputer beserta beberapa perangkat lunak yang berbasis pada pengolahan dokumen teks dan data spasial (GIS). Bahan data sekunder yang digunakan antara lain: peta rupabumi digital Kabupaten Bogor skala 1:25,000 (digital), citra ikonos Kabupaten Bogor Tahun 2010 skala 1:5,000; RTRW Kabupaten Bogor Tahun 20052025 skala 1:50,000; peta status lahan 1:50,000 Badan Pertanahan Kabupaten Bogor, dan Kabupaten Bogor dalam Angka 2011.

\section{Metode Penelitian}

Penelitian ini terdiri dari empat tahapan yaitu : tahap persiapan dan pengumpulan data, tahap analisis data spasial, tahap pengecekan lapangan, dan tahap analisis tumpang tindih evaluasi keserasian.
Tahap persiapan, meliputi pengumpulan informasi mengenai wilayah penelitian. Informasi yang dikumpulkan berupa data penggunaan lahan, status lahan dan RTRW Kabupaten Bogor Tahun 2005-2025, citra ikonos, peta status lahan, dokumen RTRW Kabupaten Bogor Tahun 2005-2025 dan data BPS Kabupaten Bogor.

Tahap analisis data spasial terdiri dari konversi data spasial analog ke bentuk digital dan analisis penggunaan lahan menggunakan citra ikonos Tahun 2010. Klasfikasi penggunaan lahan didasarkan pada warna, rona, ukuran, bentuk, tekstur, pola, bayangan, situs dan asosiasi yang tampak pada citra (Lillesland dan Kieffer, 1990). Deliniasi jenis penggunaan lahan dilakukan secara visual melakukan digitasi pada layar monitor secara langsung. Hasil dari analisis ini menghasilkan peta penggunaan lahan yang masih perlu pengecekan lapang. Digitalisasi dilakukan juga pada peta status lahan dan peta rencana pola ruang RTRW 2005-2025.

Pengecekan lapang dilakukan untuk melakukan pengecekan lapang (ground check) terhadap peta penggunaan lahan yang diperoleh dari interpretasi citra. 
Titik pengamatan ditetapkan berdasarkan kelompok jenis penggunaan lahan yang telah diidentifikasi.

Tahap selanjutnya ialah metode tumpang-tindih peta digital, yaitu: peta penggunaan lahan, peta status lahan dan peta alokasi ruang. Hasil tumpang-tindih selanjutnya dikompilasi dalam tabel (matriks) untuk melihat berapa besar proporsi dan luas penyimpangan atau ketidakselarasan yang terjadi.

\section{HASIL DAN PEMBAHASAN}

\section{Penggunaan Lahan Kabupaten Bogor Bagian Barat Saat Ini}

Penggunaan lahan di Kabupaten Bogor bagian barat diklasifikasikan menjadi 10 jenis penggunaan lahan berdasarkan hasil interpretasi dari pengolahan citra ikonos Tahun 2010. Hutan merupakan penggunaan lahan terluas, diikuti oleh kebun campuran tegalan, sawah, pemukiman, semak, perkebunan, tubuh air, pertambangan, danau dan industri. Masing-masing luas penggunaan lahan dan sebarannya dapat disajikan pada Gambar 2.
Hutan sebagai penggunaan lahan terluas menyebar mengelompok di dua bagian wilayah, yaitu bagian paling selatan dan tengah mengarah ke utara, sesuai dengan kondisi topografi wilayah pegunungan dengan kemiringan lereng yang curam (> $45 \%)$. Pola yang ditunjukkan oleh hutan membentuk blok-blok yang menyatu (kompak), dengan luas hutan yang besar. Bagian selatan merupakan kawasan TNGHS yang berada di Kabupaten Bogor dengan luas 18,000 ha. Hutan produksi dengan luas 8,680 ha terletak pada kaki TNGHS dan Kecamatan Rumpin serta Cigudeg.

Kebun campuran tersebar pada lereng yang miring dan agak curam, menyebar hampir di seluruh bagian wilayah penelitian dengan luas yang beragam. Kebun campuran di Kecamatan Jasinga ditanami tanaman buah (manggis, durian, rambutan, dan nangka) dan tanaman kayu (sengon, jabon dan afrika). Kebun campuran yang luas disebabkan karena lokasinya yang cenderung berdampingan dengan pemukiman, sawah dan tegalan. Hal ini mengindikasikan masyarakat memanfaatkan lahanlahan sempit pada kelas lereng yang beragam untuk ditanami kebun campuran.

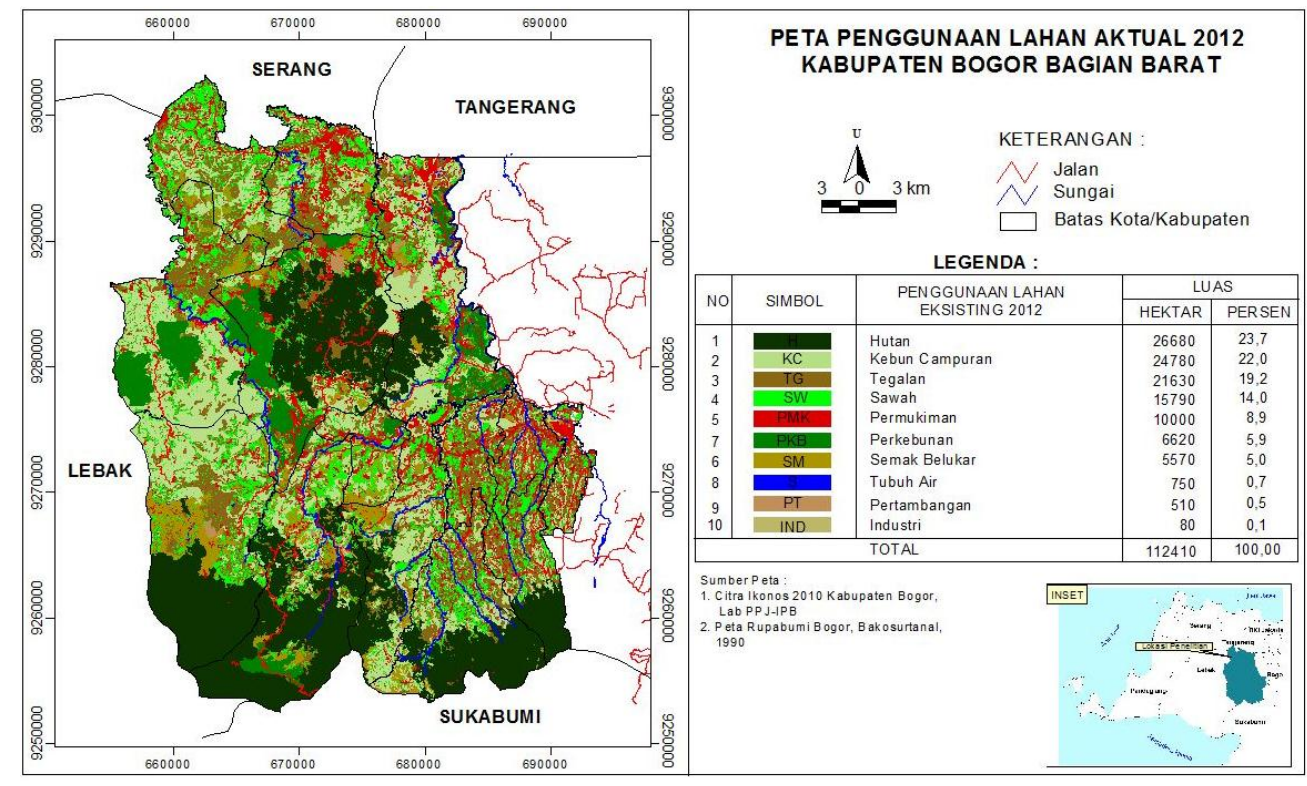

Gambar 2. Peta penggunaan lahan aktual 2012 Kabupaten Bogor bagian barat

Tegalan berada pada kemiringan lereng landai (8 $15 \%$ ) dan agak miring yang letaknya berdampingan dengan pemukiman dan sawah. Pada wilayah penelitian terdapat di bagian tengah dan utara. Sawah berada pada lereng yang landai dan bentuk wilayah datar yang tersebar di bagian utara dan tengah wilayah penelitian dengan pola menyebar.

Pemukiman tersebar pada bagian tengah dan utara wilayah penelitian dengan kelas lereng landai $(8-15 \%)$ sampai agak miring. Pola permukiman tersebar dengan luasan yang sempit. Bagian tengah dan timur wilayah penelitian berbatasan dengan Kota Bogor sehingga perkembangan pemukiman di wilayah ini tampak lebih luas.

Perkebunan terletak di bagian barat, timur, dan selatan wilayah penelitian, membentuk pola yang kompak dengan luas yang beragam. Perkebunan mendominasi wilayah dengan kelas lerang yang agak curam (15-25\%) dan letaknya bersebelahan dengan hutan. Perkebunan dengan cakupan wilayah yang paling luas dikelola oleh PTPN VIII Afdeling Cikasungka untuk sawit dan Afdeling Cianten untuk teh.

Semak belukar dengan pola yang kompak letaknya berdampingan dengan perkebunan atau hutan. Semak belukar berada pada kemiringan lereng agak curam sampai curam (25 - >40\%) dengan bentuk wilayah berbukit sampai bergunung. Pertambangan berada pada bagian utara dan selatan wilayah penelitian. Bagian utara merupakan petambangan galian $\mathrm{C}$ berupa pasir yang berada pada kelas lereng yang landai dan bentuk wilayah datar, yaitu berada di Kecamatan Rumpin. Bagian selatan merupakan pertambangan emas yang dikelola oleh PT. Antam,.Tbk., yang berada pada wilayah berbukit dengan kemiringan lereng yang curam (> 40\%).

Industri berpusat di bagian utara wilayah penelitian yang berbatasan dengan wilayah Kabupaten Tangerang, 
lereng yang landai dan bentuk wilayah yang datar. Lokasi industri yang berbatasan dengan Kabupaten Tangerang ini ditandai dengan aktivitas perekonomian yang tinggi.

\section{Status Lahan}

Status lahan adalah informasi yang menggambarkan kepemilikan lahan. Status lahan yang dimaksud disini diklasifikasikan menjadi: Tanah Negara Dikuasai, Hak Milik, Hak Guna Usaha, dan Hak Adat (Peta status lahan BPN, Kabupaten Bogor Tahun 2005). Keempat status lahan ini dijumpai di wilayah penelitian seperti disajikan pada Gambar 3.

Tanah Negara Dikuasai (TNK) pengertiannya adalah tanah yang dikuasai penuh oleh negara yang digunakan untuk dua kepentingan, yakni kepentingan Kementerian, Jawatan dan kepentingan Daerah Swatantra yang merupakan tanah-tanah yang betul-betul digunakan untuk kepentingan instansi pemerintah, baik di pusat maupun daerah, yang tercantum dalam Pasal 1 PP No.8
Tahun 1953 tentang Penguasaan Tanah-tanah Negara. TNK berada pada bagian tengah dan selatan wilayah penelitian yang berada pada kemiringan lereng yang terjal dengan luas 37,060 ha $(33.0 \%)$. Pola penyebaran pada umumnya menyatu atau kompak. TNK diantaranya merupakan bagian dari TNGHS yang diperuntukkan sebagai kawasan hutan konservasi yang berada di selatan wilayah penelitian (pegunungan).

Status Hak Milik (HM) merupakan satu-satunya hak primer yang mempunyai kedudukan paling kuat dibandingkan hak-hak lainnya. Hal ini dipertegas dalam ketentuan Pasal 20 ayat 1 UUPA yang berbunyi "Hak milik adalah hak turun temurun, terkuat, terpenuh dan yang dapat dipunyai orang atas tanah". Status lahan hak milik merupakan status lahan terluas, setelah TNK yaitu 32,370 ha $(28.8 \%)$ dan tersebar merata di seluruh wilayah penelitian. HM berada pada kelas lereng yang landai dan memiliki pola menyebar.

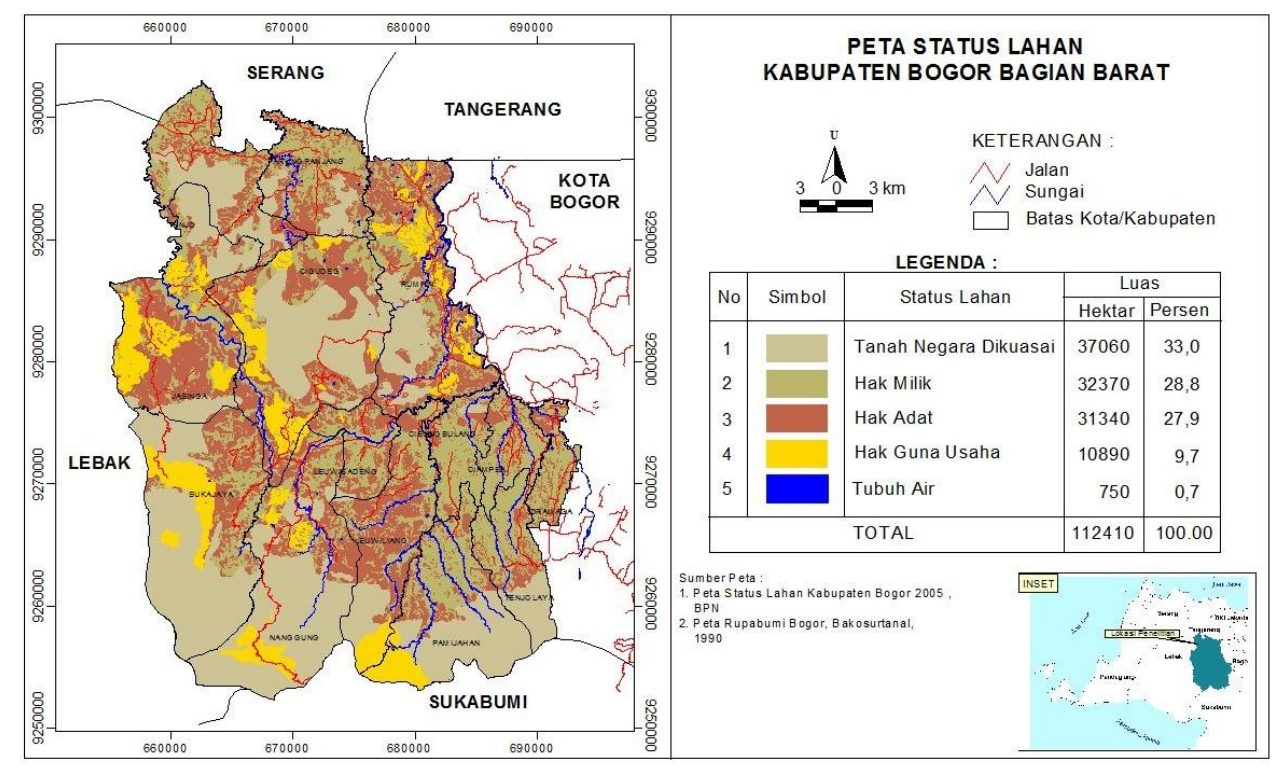

Gambar 3. Peta status lahan Kabupaten Bogor bagian barat

Hak Adat (HA) adalah suatu sifat komunalistik yang menunjuk adanya hak bersama oleh para anggota masyarakat hukum adat atas suatu tanah tertentu. Dalam pelaksanaannya kelompok tersebut bisa merupakan hukum adat yang teritorial (desa, marga magari, hutan) bisa juga merupakan hukum adat geneologik atau keluarga, seperti suku. HA tidak hanya berwujud tanah yang dijadikan perkampungan, sawah dan kebun saja, tetapi meliputi pula hutan-belukar, padang ilalang, rawa-rawa, sungai-sungai, bahkan laut di sekitarnya (Abna, 2007). HA di wilayah penelitian letaknya berdampingan dengan hak milik dan memiliki pola yang serupa yaitu menyebar tidak beraturan dengan luas yang beragam. Khusus di Kecamatan Sukajaya terdapat objek wisata kampung adat "Urug" yang dikonservasikan oleh Pemerintah Kabupaten Bogor.

Hak Guna Usaha (HGU) menurut Pasal 28 Undangundang Nomor 5 Tahun 1960 Tentang Undang-undang Pokok Agraria adalah hak khusus untuk mengusahakan tanah yang bukan miliknya sendiri atas tanah yang dikuasai langsung oleh negara untuk perusahaan pertanian, perikanan atau peternakan. HGU memiliki luas minimal 5 hektar dan maksimum 25 hektar untuk perseorangan. Di wilayah penelitian $\mathrm{HGU} 10,890$ ha (9.7\%) yang merupakan status lahan terkecil dibandingkan lainnya, dengan pola sebaran yang kompak, berada pada kemiringan lereng agak curam dengan bentuk wilayah berbukit. Status Hak Guna Usaha sebagian besar didominasi oleh penggunaan lahan perkebunan komoditas kelapa sawit yang dikelola oleh PTPN VIII Afdeling Cikasungka dan teh yang dikelola oleh Afdeling Cianten.

\section{Alokasi Ruang di Wilayah Kabupaten Bogor Bagian Barat}

Berdasarkan RTRW Kabupaten Bogor Tahun 20052025 wilayah Kabupaten Bogor bagian barat terdiri atas kawasan lindung dan kawasan budidaya dengan luas masing-masing 16,890 ha $(15.0 \%)$ dan 92,580 ha $(82.4 \%)$. Sebaran spasial alokasi ruang wilayah penelitian dapat disajikan pada Gambar 4.

Alokasi ruang pada Kawasan Lindung terdiri atas kawasan hutan lindung (KHL) dan kawasan hutan 
konservasi (KHK). Luas kawasan hutan konservasi TNGHS yang berada pada wilayah penelitian seluas 18,000 ha dari 113,357 ha total luas TNGHS berdasarkan
SK Menteri Kehutanan No. 175/Kpts-II/2003, sementara berdasarkan pola ruang yang diperuntukan sebagai Kawasan Lindung seluas 16,890 ha.

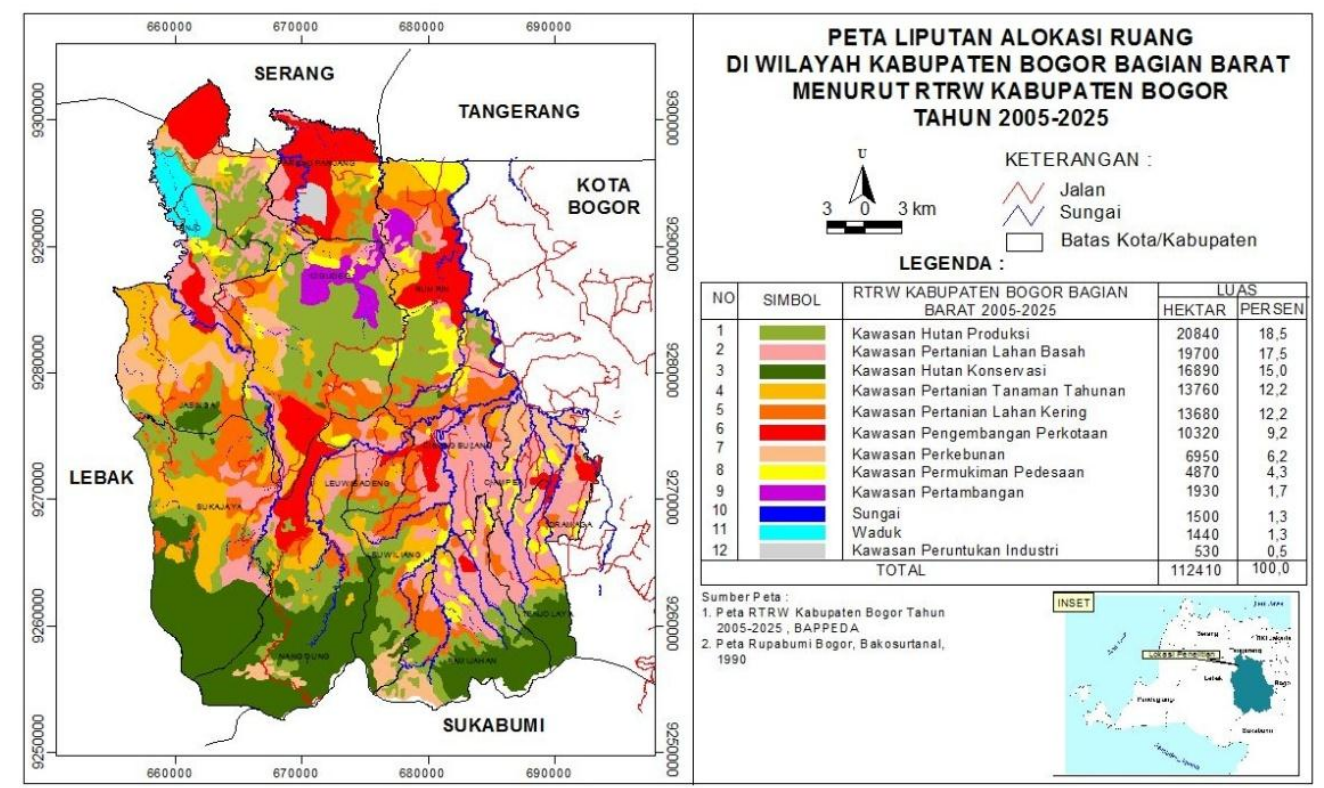

Gambar 4. Liputan alokasi ruang di wilayah Kabupaten Bogor bagian barat menurut RTRW Kabupaten Bogor tahun 2005-2025

Kawasan budidaya terdiri atas kawasan hutan produksi, pertanian lahan basah, pertanian tanaman tahunan, pertanian lahan kering, pengembangan perkotaan, perkebunan, pemukiman pedesaan, pertambangan dan peruntukan industri. Penggunaan lahan yang merupakan Kawasan Budidaya memiliki luas 85,730 ha, lebih sempit 6,850 ha dibandingkan peruntukannya yang dialokasikan dalam RTRW Kabupaten Bogor Tahun 2005-2025.

\section{Hubungan Penggunaan Lahan, Alokasi Ruang dan Status Lahan Kabupaten Bogor Bagian Barat}

Matriks hubungan antar penggunaan lahan, status lahan dan alokasi ruang di Kabupaten Bogor bagian Barat disajikan pada Tabel 1, 2 dan 3. Alokasi ruang untuk
Kawasan Hutan Lindung dalam wilayah penelitian adalah kawasan hutan konservasi. Idealnya dalam kawasan hutan konservasi hanya penggunaan lahan yang memiliki fungsi konservasi. Namun demikian kondisi di lapangan menunjukkan adanya penggunaan lahan lain yang tidak sesuai dengan fungsinya. Penggunaan lahan yang dominan adalah hutan sesuai dengan peruntukannya sebagaimana diatur dalam rencana pola ruang RTRW Kabupaten Bogor Tahun 2005-2025. Kawasan hutan konservasi masih terdapat penggunaan lahan lain yang tidak berfungsi konservasi yaitu: kebun campuran, tegalan, sawah, perkebunan dan permukiman. Dari penggunaan lahan yang tidak berfungsi konservasi tersebut yang proporsinya paling besar adalah kebun campuran.

Tabel 1. Luas penggunaan lahan pada alokasi ruang kawasan lindung dan status lahan di wilayah penelitian

\begin{tabular}{llllrr}
\hline \multirow{2}{*}{ No } & \multirow{2}{*}{ Alokasi Ruang } & \multirow{2}{*}{ Penggunaan Lahan } & Status Lahan & Hektar & Proporsi (\%) \\
\cline { 5 - 6 } 1 & \multirow{2}{*}{ Kawasan Hutan Konservasi } & Hutan & HA, HGU \& TNK & 14,440 & 85.49 \\
& & Kebun Campuran & HA, HGU \&TNK & 650 & 3.85 \\
& Semak Belukar & HA, HGU \& TNK & 630 & 3.73 \\
& Tegalan & HA, HGU, HM \& TNK & 570 & 3.37 \\
& Sawah & HA, HGU, HM \& TNK & 380 & 2.25 \\
& Perkebunan & HGU \& TNK & 140 & 0.83 \\
& & Permukiman & HA \& TNK & 80 & 0.47 \\
\hline
\end{tabular}

Berdasarkan keadaan lapang dan analisis data poligon-poligon dengan luasan yang kecil, keberadaan kebun campuran di kawasan hutan konservasi merupakan fakta aktual di lapangan. Hal ini terutama terkait dengan adanya petani tradisional yang sudah tinggal di wilayah ini sebelum ditetapkan sebagai kawasan hutan konservasi oleh pemerintah daerah (enclave dalam kawasan).
Alokasi ruang kawasan budidaya yang terdapat dalam wilayah penelitian yaitu : Kawasan Hutan Produksi, Pertanian Lahan Basah, Pertanian Tanaman Tahunan, Pertanian Lahan Kering, Permukiman Perkotaan, Perkebunan, Permukiman Pedesaan, Pertambangan dan Peruntukan Industri (Tabel 2). 
Penggunaan lahan kebun campuran luasnya dominan hampir di seluruh kawasan dengan status lahan Hak Guna Usaha, Hak Adat dan Hak Milik. Hasil wawancara diperoleh informasi bahwa di Kecamatan Sukajaya, masyarakat memanfaatkan lahan bekas HGU yang dikuasai oleh pemerintah sebagai sebagai kebun campuran. Konflik yang pernah terjadi terkait pemanfaatan HGU terlantar berada di Kecamatan Nanggung.
Perkebunan Karet PT. Hevea menelantarkan perkebunan karet selama 20 tahun (1993-2013) yang akhirnya dimanfaatkan oleh masyarakat. Perusahaan mengalami kerugian dengan pengurangan luas lahan dari 1,200 ha menjadi 310 ha. Selain itu usaha masyarakat untuk meminta tanah untuk digarap, dipatahkan dengan dikeluarkannya surat perpanjangan HGU oleh Bupati dan Distanhut Kabupaten Bogor pada Tahun 2011.

Tabel 2. Luas penggunaan lahan pada setiap alokasi ruang di kawasan budidaya dan status lahan di wilayah penelitian

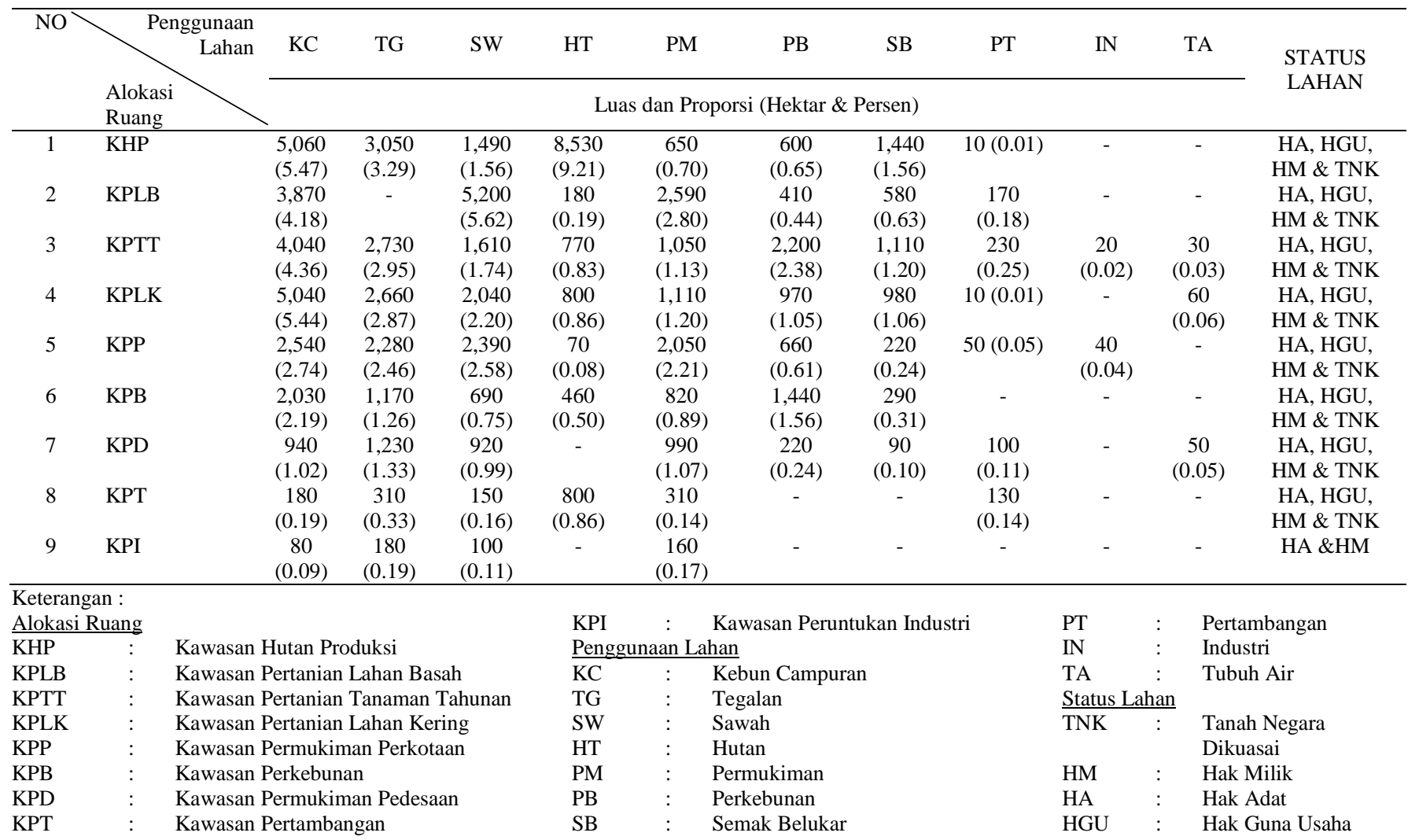

Tabel 3. Hubungan status lahan dengan penggunaan lahan Kabupaten Bogor bagian barat

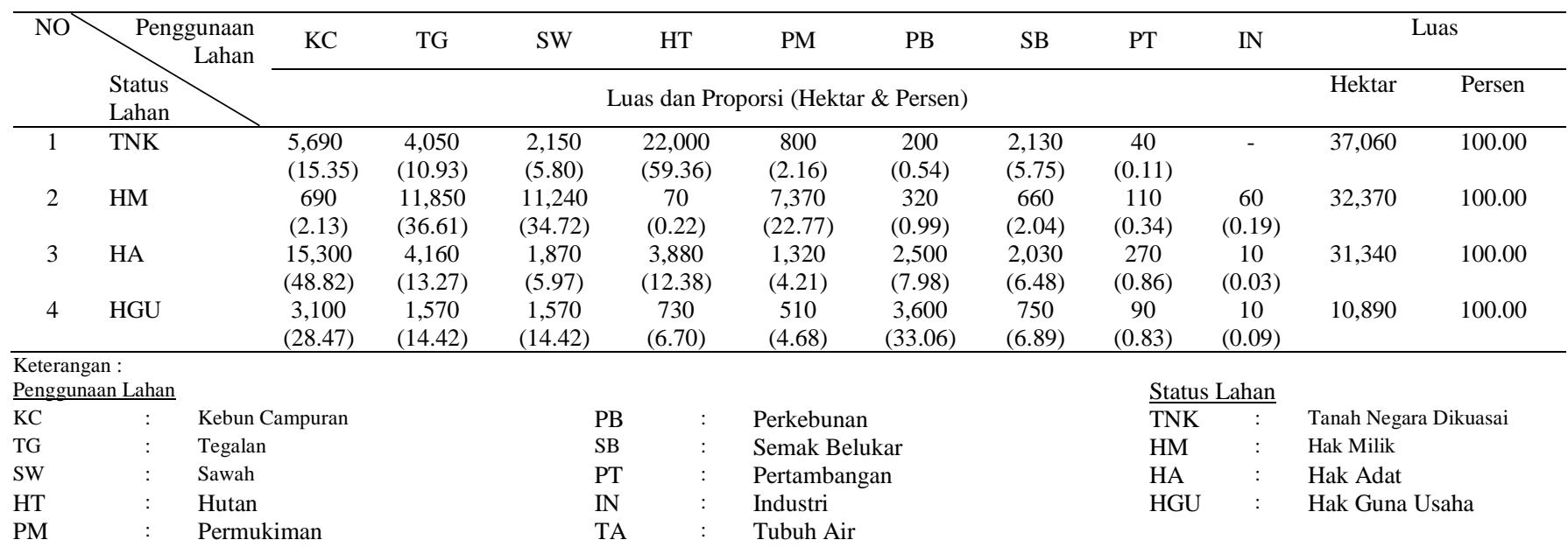

Masing-masing status lahan memiliki luas dan proporsi yang berbeda di masing-masing penggunaan lahan (Tabel 3) dan persebarannya disajikan pada Gambar 5. Pada status TNK didominasi oleh hutan, yang memang sesuai dengan peruntukannya. Penggunaan lahan lain dengan luas yang sempit yaitu kebun campuran, tegalan, sawah, permukiman, perkebunan dan pertambangan. Hal ini disebabkan antara lain pada tanah yang dikuasai oleh PTPN VIII dan TNGHS terdapat masyarakat yang memiliki hak garap di dalam kawasannya.

Hak Milik didominasi penggunaan lahan tegalan, dilanjutkan dengan sawah, pemukiman, kebun campuran, semak belukar, perkebunan, pertambangan, hutan dan industri. Hutan merupakan bagian dari ketidakselarasan 
karena berada dalam Hak Milik yang idealnya dimanfaatkan oleh masyarakat untuk kegiatan yang bernilai ekonomis tinggi. Keberadaan hutan dalam HM terjadi karena perbedaan skala peta dalam pengolahan data spasial, sehingga menimbulkan poligon-poligon kecil (sliver) hasil tumpangtindih. HA pada umumnya penggunaan lahan sesuai, yaitu : kebun campuran, diikuti dengan tegalan, hutan, perkebunan, semak belukar, sawah, pemukiman, pertambangan dan industri. Ketidakselarasan terjadi ketika industri berada dalam HA, idealnya industri dikembangkan pada lahan dengan status yang kuat secara badan hukum seperti HM.
Hak Guna Usaha (HGU) dengan penggunaan lahan terluas adalah perkebunan, selaras dengan peruntukannya. Penggunaan lahan lain yang tidak selaras yaitu kebun campuran, tegalan, hutan, semak belukar, sawah, pemukiman, pertambangan dan industri. Penggunaan lahan tersebut tidak selaras karena merupakan bentuk aktivitas masyarakat sekitar yang tidak seharusnya dilakukan pada lahan HGU, secara resmi masyarakat diberikan hak garap oleh pihak perusahaan. Secara tidak resmi masyarakat memanfaatkan lahan yang ditelantarkan oleh pihak perusahaan.

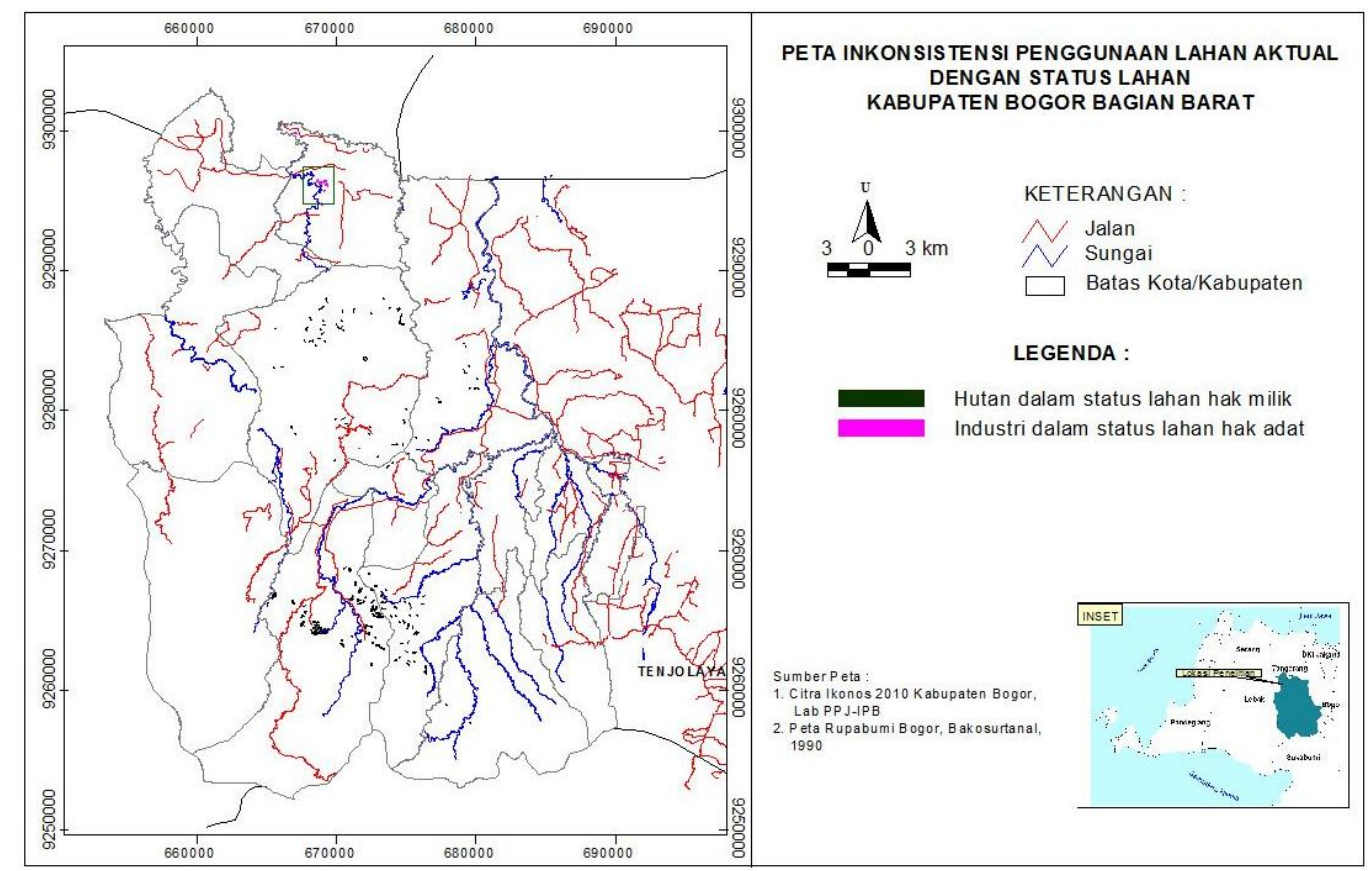

Gambar 5. Inkonsistensi penggunaan lahan dengan status lahan

\section{SIMPULAN}

1. Penggunaan lahan saat ini di wilayah Kabupaten Bogor bagian Barat terdiri dari 10 jenis penggunaan lahan berdasarkan hasil interpretasi citra ikonos Tahun 2010 dan hasil verifikasi lapang, diurutkan dari yang terluas sampai tersempit yaitu: hutan, kebun campuran tegalan, sawah, pemukiman, semak, perkebunan, tanah kosong, sungai, pertambangan, danau dan industri.

2. Secara garis besar penggunaan lahan saat ini sudah selaras dengan alokasi ruang dan status lahan. Namun demikinan terdapat beberapa ketidakselarasan yaitu penggunaan lahan selain hutan yang dialokasikan di kawasan hutan konservasi dengan status Tanah Negara Dikuasai dan adanya aktivitas masyarakat di dalam kawasan perkebunan. Kebun campuran merupakan penggunaan yang dijumpai di seluruh alokasi ruang dan status lahan yang berbeda dengan luas yang beragam.

\section{DAFTAR PUSTAKA}

Abna, B. 2007. Pengelolaan tanah negara dan tanah ulayat [Laporan]. Badan Perencanaan
Pembangunan Nasional, Kementrian Negara Perencanaan Pembangunan.

[Bappeda] Badan Perencanaan Daerah Kabupaten Bogor. 2006. Laporan Penelitian Awal Pengembangan Wilayah Kabupaten Bogor. Bogor.

[BPS] Badan Pusat Statistik Kabupaten Bogor. 2010. Kabupaten Bogor Dalam Angka 2010. Bogor.

Lambin, E., H.J. Geist, and E. Lepers. 2003. Dynamic Of Land-Use and Land-Cover Change In Tropical Region. Annu Rev Environ Resource 28:2005-41. Doi: 10.1146/annurev.energy.280503.105459.

Lillesand, T.M. dan R.W. Kiefer. 1990. Penginderaan Jauh dan Interpretasi Citra. Gadjah Mada University Press. Yogyakarta.

Maharani, S. 2011. Struktur agraria masyarakat desa hutan dan implikasinya terhadap pola pemanfaatan sumberdaya agraria (studi kasus: masyarakat Kampung Pel Cianten, Desa Purasari, Kecamatan Leuwiliang, Provinsi Jawa Barat) [Tesis]. IPB. Bogor. 
Marisan, M. 2006. Analisis penyimpangan tata ruang dilihat dari aspek fisik wilayah: kasus Kabupaten dan Kota Bogor [Tesis]. IPB. Bogor.

[Perda] Peraturan Daerah Nomor 19. 2008. Rencana Tataruang Wilayah Kabupaten Bogor. Bogor.

Presiden Republik Indonesia. 1953. Peraturan Pemerintah Indonesia Nomor 8 Tahun 1953 tentang Penguasaan Tanah-Tanah Negara.
1960. Undang-Undang Republik Indonesia Nomor 5 Tahun 1960 tentang Peraturan Dasar Pokok Agraria.

2007. Undang-undang Negara Republik Indonesia Nomor 26 tahun 2007 tentang Penataan Ruang. 